\title{
DEFICITUL DE FIER ŞI ANEMIA PRIN DEFICIT DE FIER - PROBLEMĂ GLOBALĂ DE SĂNĂTATE PUBLICĂ
}

\author{
Laura Florescu, Oana-RalucaTemneanu, Nicolai Nistor, Dana Elena Mîndru \\ Universitatea de Medicină şi Farmacie ,, Gr. T. Popa“, Iaşi
}

\begin{abstract}
REZUMAT
Deficitul de fier este definit ca o stare în care nu există un nivel corespunzător de fier necesar pentru a menține functiiile normale fiziologice ale organismului. Anemia este o problemă globală de sănătate publică, de proporțiile unei epidemii, care afectează atât țările în curs de dezvoltare cât şi țările dezvoltate, cu consecințe majore pentru sănătatea umană, precum şi dezvoltarea socială şi economică. În prezent, deficitul de fier şi în special anemia prin carență de fier rămâne una dintre deficiențele nutriționale cele mai grave şi importante din lume. Fiecare grupă de vârstă este vulnerabilă. Sugarii, copiii mici, preşcolarii şi adolescenții prezintă un risc mai mare de a dobândi deficit de fier, de aceea Organizația Mondială a Sănătății (OMS) a elaborat un pachet cuprinzător de măsuri de sănătate publică care abordează toate aspectele legate de un deficit de fier şi anemia feriprivă. În încercarea de a diminua prevalența deficitului de fier şi a anemiei feriprive, Societatea Europeană de Gastroenterologie, Hepatologie şi Nutriție Pediatrică (The European Society for Paediatric Gastroenterology Hepatology and Nutrition-ESPGHAN) a sintetizat în 2014 recomandările utilizate şi în prezent privind profilaxia marțială.
\end{abstract}

Cuvinte cheie: fier, carența nutritională, deficit de fier, anemie feriprivă

Fierul este un mineral important, implicat în diferite funcții ale corpului, inclusiv transportul oxigenului în sânge. Acest lucru este esențial în furnizarea de energie pentru viața de zi cu zi.

Deficitul de fier este definit ca o stare în care nu există un nivel corespunzător de fier necesar pentru a menține funcțiile normale fiziologice; acesta rezultă din absorbția inadecvată de fier, astfel încât nu poate fi acoperit necesarul pentru buna funcționare a organismului şi creşterii, sau dintr-un sold negativ de fier pe termen lung. Oricare dintre aceste situații duce la o scădere a depozitelor de fier, măsurată prin concentrațiile serice ale feritinei sau cantității de fier din măduva osoasă. Deficitul de fier poate fi însoțit sau nu de anemie (1).

Anemia este o problemă globală de sănătate publică, de proporțiile unei epidemii, care afectează atât țările în curs de dezvoltare cat şi țările dezvoltate, cu consecințe majore pentru sănătatea umană, precum şi dezvoltarea socială şi economică. Datele sunt îngrijorătoare: 2 miliarde de oameni, reprezentând peste $30 \%$ din populaţia lumii, sunt anemici, mulţi din cauza deficitului de fier. În zonele cu resurse sărace, acest lucru este în mod frecvent exacerbat de o serie de alte condiții patologice, cum ar fi malaria, infecțiile parazitare, HIV/SIDA, schisto- somiasis, tuberculoza, alte deficiențe nutriționale şi hemoglobinopatii ce reprezintă factori deosebit de importanți, care contribuie la prevalența ridicată a anemiei în unele zone (2). La nivel global, se estimează că aproximativ $25 \%$ din copiii preşcolari au deficit de fier. Prevalența anemiei feriprive la sugari în Europa este de obicei $<2 \%$ înainte de vârsta de 6 luni, aproximativ $2 \%$ până la $3 \%$, la 6 până la 9 luni şi 3\% până la $9 \%$, de la 1 la 3 ani. În mod similar, prevalența deficitului de fier este cea mai ridicată între 1 şi 3 ani, întrucât cifrele europene de prevalență variază de obicei între 5\% şi 20\% (3).

În prezent, deficitul de fier şi în special anemia prin carența de fier rămâne una dintre deficiențele nutriţionale cele mai grave şi importante din lume. Fiecare grupă de vârstă este vulnerabilă. Rolul fierului se exercită încă din primele luni de viață, fapt ce impune evitarea unor deficiențe de fier încă din perioada de nou-născut şi sugar, pentru a preveni unele complicații ireversibile.

Sugarii, copiii mici, preşcolarii şi adolescenții prezintă un risc mai mare de a dobândi deficit de fier, în principal din cauza nevoilor crescute de fier în timpul perioadelor de creştere rapidă. Fără intervenție la momentul oportun, un copil a cărui dietă 
nu oferă suficient fier va dezvolta în cele din urmă anemie prin deficit de fier.

Deficitul de fier afectează dezvoltarea cognitivă a copiilor până la adolescență şi mielinizarea, contribuie la reducerea metabolismului energetic, are implicații în ADHD (Attention Deficit Hyperactivity Disorder) şi sindromul ,picioarelor neobosite“ şi, de asemenea, are un impact negativ asupra mecanismelor imune nespecifice şi specifice, şi astfel este asociat cu creşterea morbidităţii (4).

În timpul sarcinii, deficitul de fier se coreleză cu mai multe rezultate negative, atât pentru mamă cât şi pentru copil, inclusiv un risc crescut de hemoragie, sepsis, mortalitate maternă, mortalitate perinatală şi greutate mică la naştere (5). Se estimează că aproape toate femeile au într-o oarecare măsură deficit de fier, şi mai mult de jumătate dintre femeile gravide în țările în curs de dezvoltare suferă de anemie (6). Chiar şi în țările industrializate, depozitele de fier la cele mai multe femei gravide sunt considerate deficitare. În cele din urmă, o depreciere de $30 \%$ a capacității de muncă fizică şi performanță este raportată atât la femeiile, cât şi la bărbații cu carență de fier. Implicațiile economice ale deficitului de fier şi diferitelor strategii de intervenție pentru combaterea lor sugerează că abordările bazate pe produse alimentare îmbogăţite şi suplimente sunt deosebit de eficiente. Cel mai mare raport beneficiu-cost este atins prin îmbogăţirea alimentelor (7).

Fierul este esențial pentru toate celulele. Funcțiile fierului includ:

- implicarea în metabolismul energetic;

- reglarea genelor;

- creşterea şi diferenţierea celulară;

- legarea şi transportul oxigenului;

- utilizarea oxigenului muscular şi stocarea;

- reacțiile enzimatice;

- sinteza neurotransmițătorilor;

- sinteza proteinelor.

Nevoile de fier sunt mai mari la adolescenții de sex masculin, în timpul vârfului pubertății, din cauza unei creşteri mai mari a volumului sanguin, masei musculare şi mioglobinei (8).

După instalarea menstruației, nevoile de fier continuă să rămână ridicate la femei, din cauza pierderii de sânge menstrual, care se situează în medie la aproximativ $20 \mathrm{mg}$ de fier pe lună, iar în unele situații particulare poate să ajungă până la 58 $\mathrm{mg}$. Contraceptivele orale scad pierderile menstruale, în timp ce unele dispozitive intrauterine pot mări aceste pierderi. În ciuda nevoilor crescute de fier, mulți adolescenți, în special fetele, pot avea aportul de fier de numai $10-11 \mathrm{mg} / \mathrm{zi}$ de fier total, ducând la aproximativ $1 \mathrm{mg}$ de fier absorbit. Aproximativ trei sferturi dintre adolescente nu reuşesc să acopere cerințele de fier dietetice, comparativ cu 17\% dintre adolescenții de sex masculin (9).

În mod convențional, se consideră că deficitul de fier evoluează în 3 stadii:

- epuizarea depozitelor de fier;

- eritropoieza deficitară;

- anemia feriprivă.

În primul stadiu, depozitele de fier sunt epuizate, aspect cuantificat prin dozarea feritinei serice, dar aceasta reprezintă un reactant de fază acută, fiind modificată în stări infecțioase sau inflamatorii. Gradul de saturare a transferinei (raportul dintre fierul seric şi transferină) este un marker mai fiabil decât sideremia şi va scădea în prima sau a doua etapă a deficitului de fier. Totuşi, feritina este mai frecvent utilizată decât gradul de saturare a transferinei ca marker de epuizare a fierului din organism.

În a doua etapă, în eritropoieza fier-deficitară receptorii serici pentru transferină cresc în plasmă ca marker de nevoi crescute de fier în țesuturile organismului. Mai mult decât atât, zinc-protoporfirina eritrocitară din celulele roşii din sânge va creşte, în timp ce concentrația de hemoglobină $(\mathrm{Hb})$ va scădea.

În etapa a treia, de anemie feriprivă, concentrația de hemoglobină din sânge va fi redusă, iar indicii eritrocitari vor fi scăzuţi (10). Combinația dintre $\mathrm{Hb}$ şi feritină este considerată cea mai sensibilă în măsurarea eficienței administrării de fier, atât la copii, cât şi la adulți (11) (Tabelul 1).

TABELUL 1. Anemia feriprivă - ESPGHAN: Valorile de referință sugerate pentru definirea anemiei şi valorile feritinei serice la diferite vârste

\begin{tabular}{|l|c|c|c|c|c|}
\hline \multirow{2}{*}{ Marker } & \multicolumn{5}{|c|}{ Vârsta } \\
\cline { 2 - 6 } & $\mathbf{0 - 1}$ săpt. & 2 luni & 4 luni & $6-24$ luni & 2-5 ani \\
\hline Hemoglobina $(\mathrm{g} / \mathrm{L})$ & 135 & $\mathbf{9 0}$ & 105 & 105 & 110 \\
\hline $\begin{array}{l}\text { Feritina serică } \\
(\mu \mathrm{g} / \mathrm{L})\end{array}$ & 40 & 40 & 20 & $10-12$ & $10-12$ \\
\hline
\end{tabular}

Factorii de risc asociați cu o mai mare prevalență a carenței în fier, includ greutatea mică la naştere, alimentația cu lapte de vacă, aportul redus de alimente complementare bogate în fier sau alimentația complementară (diversificată) incorectă, alimentația vegetariană, afecțiunile gastrointestinale, saturnismul, statusul socio-economic precar, statutul de imigrant.

Primele 6 luni de viață, cunoscute ca perioada cu cel mai accelerat ritm de creştere, când se epuizează rezervele de fier, reprezintă perioada cea mai critică a vieții pentru menținerea echilibrului dinamic între cerințele nutriţionale şi aportul de fier. În 
primele 4 luni de viață, fierul este asigurat de lapte. Laptele matern conține 1,0-1,5 mg Fe/litru, din care se absoarbe $50 \%$ spre deosebire de laptele de vacă integral, care conține $1 \mathrm{mg} \mathrm{Fe} / \mathrm{litru}$, din care se absoarbe doar $10 \%$ (12).

Intervențiile propuse pentru prevenirea deficitului de fier la diferite vârste includ suplimentarea cu fier la femeile gravide, pensarea mai târzie a cordonului ombilical, suplimentarea cu fier la sugari şi copiii cu greutate mică la naştere (picături de fier), formule de lapte îmbogățite cu fier, alimentație complementară corectă, evitarea alimentației cu lapte de vacă. Societatea Europeană de Gastroenterologie, Hepatologie şi Nutriţie Pediatrică a furnizat recomandările cu privire la cerințele de fier la sugari şi copii (Tabelul 2).

TABELUL 2. Aportul de fier pe grupe de vârstă conform Ghidului ESPGHAN 2014 (3)

\begin{tabular}{|c|c|c|c|}
\hline Sugari 6 luni - 1 an & Copii 1-3 ani & Copii 4-8 ani & Copii 9-13 ani \\
\hline $\begin{array}{c}0,9-1,3 \\
\mathrm{mg} / \mathrm{kg} \text { corp }\end{array}$ & $\begin{array}{c}0,5-0,8 \\
\mathrm{mg} / \mathrm{kg} \text { corp }\end{array}$ & $\begin{array}{c}0,3-0,5 \\
\mathrm{mg} / \mathrm{kg} \text { corp }\end{array}$ & $\begin{array}{c}0,2-0,3 \\
\mathrm{mg} / \mathrm{kg} \text { corp }\end{array}$ \\
\hline $7,8-11 \mathrm{mg}$ & $5,8-9 \mathrm{mg}$ & $6-10 \mathrm{mg}$ & $8-11 \mathrm{mg}$ \\
\hline
\end{tabular}

Suplimentele de fier (de exemplu, fier picături) nu sunt de obicei recomandate pe termen lung, la copiii alăptați la sân în primele luni de viață; ESPGHAN concluzionează că nu există dovezi convingătoare că suplimentele de fier ar trebui administrate la sugarii cu greutate normală la naştere, alimentați exclusiv natural în timpul primelor 6 luni de viață, în rândul populațiilor cu o prevalență scăzută a anemiei feriprive.

Din cauza biodisponibilității mult mai mici a fierului conținut în formulele de lapte comparativ cu laptele uman, formulele de început au concentrații de fier mai mari decât în laptele matern; cu toate acestea, a existat o controversă îndelung dezbătută în ceea ce priveşte nivelul optim de fortifiere cu fier a preparatelor pentru sugari.

În prezent, cele mai multe formule standard pentru sugari, în Europa, au fier în concentrație de 4 până la $8 \mathrm{mg} / 1$. Pe baza dovezilor de mai sus, precum şi a prevalenței scăzute a anemiei feriprive la 6 luni în Europa, ESPGHAN consideră această practică sigură şi eficientă, dar există în mod clar necesitatea unor studii randomizate controlate pentru a determina cu acuratețe nivelul adecvat de fier în formulele pentru sugari.

Sugarii cu greutate mică la naştere (low birth weight - LBW), au o cantitate totală de fier în organism mai mică şi o rată de creştere mai mare, comparativ cu cei cu greutatea normală la naştere, de aici şi nevoile crescute de fier, chiar înainte de a împlini 6 luni. Ghidul ESPGHAN concluzionează că administrarea a 1-2 mg Fe/kg corp/zi, începând în intervalul 2-6 săptămâni de viață, la sugarii cu greutate mică la naştere (2.000-2.500 g), până la vârsta de 6 luni previne instalarea anemiei feririve, fără efecte adverse şi reduce riscul apariției de tulburări comportamentale mai târziu. Sugarii LBW, cu greutate la naştere $<2.000 \mathrm{~g}$, trebuie să primească suplimente de fier, la o doză de 2 până la $3 \mathrm{mg} /$ $\mathrm{kg}$, în conformitate cu liniile directoare ESPGHAN pentru nutriția enterală a copiilor prematuri.

De la vârsta de 6 luni, toți sugarii şi copiii mici ar trebui să primescă alimente bogate în fier în alimentaţia complementară şi/sau alimente fortificate cu fier.

Laptele de vacă integral nu ar trebui administrat înaintea vârstei de 1 an, iar după această vârstă, cantitatea trebuie limitată la maximum 500 ml/zi.

Semnele şi simptomele deficitului de fier la copii pot include: probleme de comportament, scăderea performanțelor cognitive, infecții repetate, pierderea poftei de mâncare, letargie, dispnee, transpirație crescută, preferințe alimentare ciudate (pica), dezvoltare staturo-ponderală nesatisfăcătoare, scăderea rezistenței la efort, reducerea forței musculare (13).

\section{Strategii dietetice}

Sursele de fier alimentare sunt reprezentate de peşte şi carne de pasăre, linte, fasole uscată, produse din cereale, legume, fructe uscate şi melasă; cele de origine animală sunt absorbite în mod eficient de către receptorii din intestin, în timp ce biodisponibilitatea fierului din plante este determinată de prezența unor factori alimentari care îmbunătățesc sau inhibă absorbția acestuia (14).

\section{Reacții adverse posibile ale fierului}

Este important de remarcat faptul că fierul este un puternic pro-oxidant şi că, spre deosebire de majoritatea celorlalte nutriente, nu poate fi eliminat în mod activ. La adulți, riscul de supraîncărcare cu fier este, în principal limitat la persoanele cu hemocromatoză ereditară; la copii, riscul de supraîncărcare cu fier trebuie luat în considerare şi la cei fără această predispoziție genetică. Suplimentarea excesivă cu fier la sugari poate avea efecte adverse, de exemplu, un risc crescut de afectare neuronală, reducerea capacității de apărare imunitară şi o dezvoltare necorespunzătoare (15). Pentru că un consum ridicat de fier poate avea efecte negative, este important să se identifice cerințele de fier şi să se identifice grupurile de risc care trebuie să beneficiaze de un aport crescut de fier. De asemenea, este 
important să se păstreze suplimentele de fier bine închise şi departe de accesul copiilor, deoarece, nu de puține ori, cele sub formă de comprimate au fost confundate cu acadele de către copii.

În prezent, se discută despre conceptul pluricarențial al anemiei. De aceea, pe lângă deficitul de fier, trebuie luată în considerare deficiența altor oligoelemente (Cupru, Zinc), precum şi a vitamine lor (vitamina $\mathrm{C}$, vitamine din grupul $\mathrm{B}-\mathrm{B}_{2}, \mathrm{~B}_{6}, \mathrm{~B}_{9}$, $\left.\mathrm{B}_{12}\right)$, cu care se asociază relativ frecvent, şi despre care se cunoaşte că sunt implicate în metabolismul fierului în organism şi în hematopoieză.

OMS a elaborat un pachet cuprinzător de măsuri de sănătate publică, care abordează toate aspectele legate de deficitul de fier şi carențele nutriționale asociate şi anemia feriprivă. Acest pachet este implementat în țările cu un nivel ridicat de deficit de fier şi anemie, precum şi o rată crescută de infecții. Printre măsurile elaborate, se numără:

- creşterea aportului de fier: diversificarea cu alimente bogate în fier, inclusiv preparatele industriale şi suplimente de fier;

- controlul infecțiilor: programe de imunizare, precum şi controlul pentru boli infecțioase (malaria, schistosomiasis);

- îmbunătăţirea statusului nutriţional: prevenirea şi controlul altor deficiențe nutriționale, cum ar fi cea de Cupru, Zinc sau Vitamine $\mathrm{C}, \mathrm{B}_{2}, \mathrm{~B}_{6}, \mathrm{~B}_{9}, \mathrm{~B}_{12}$ şi vitamina A (2).

\section{CONCLUZII}

Deficitul de fier şi anemia feriprivă reprezintă o problemă de sănătate publică. Este imperios necesară monitorizarea grupelor de vârstă cu risc, pentru a preveni instalarea semnelor clinice, unele cu impact pe termen lung. De asemenea, nu trebuie ignorate carențele nutriționale asociate frecvent $\mathrm{cu}$ deficitul de fier, astfel încât beneficiul terapeutic să fie rapid şi eficient. Recomandările societăților ştiinţifice de specialitate sunt mereu revizuite, dar în continuare sunt necesare studii ample în ceea ce priveşte perioada optimă de iniţiere a profilaxiei, doza adaptată grupei de vârstă, particularităților individuale şi cerințelor nutriţionale.

Deoarece reprezintă o problemă de sănătate publică cu implicații majore socio-economice, recomandările OMS s-au constituit într-un pachet de măsuri, ce trebuie implementat în toate zonele cu prevalență crescută pentru această carență nutrițională. 